\title{
Heavy metal phytoremediation: Potential and advancement
}

\author{
Pushpa Chaudhary Tomar ${ }^{\mathrm{r}^{*}}$, Shilpa Samir Chapadgaonkar ${ }^{\mathrm{a}}$, Varsha Panchal ${ }^{\mathrm{a}}$, Arpita Ghosh ${ }^{\mathrm{b}}$ \\ ${ }^{a}$ Department of Biotechnology, Faculty of Engineering \& Technology, Manav Rachna International Institute Research and Studies, \\ 121001 (Faridabad) India \\ ${ }^{b}$ Indian Institute of Management Sirmaur, 173025 (Paonta Sabib, Himachal Pradesh) India
}

Received 25th May 2020 / Accepted 16th September 2020

\begin{abstract}
Industrial activities lead to the release of different types of toxic metals into the environment. Phytoremediation has been established as one of the environmental-friendly and economical processes that have the potential for the remediation of industrial waste. Phytoremediation is used to extract metals from industrial effluents using ex-situ and in-situ treatments. Also, phytoremediation may be used to reclaim the polluted land resource for agricultural purposes. Moreover, this also prevents the bioaccumulation and biomagnification of xenobiotics from farming activities if carried out from polluted land. Phyto-mining can be done to recover and reuse the heavy metals from plant tissues after phytoremediation by plants. This study aimed to give a comprehensive review of recent research work in heavy metal phytoremediation.
\end{abstract}

Keywords: Bioaccumulation, biomagnification, contaminants, heavy metals, phytoremediation

\section{INTRODUCTION}

Pollution by heavy metals has a serious impact on the environment (Ali et al., 2013). The high concentration of heavy metals has very harmful effects on human health, plants, and animals (Djingova et al., 2000). Major sources of heavy metal in the soil are fertilisers, wastewater, sewage sludge, pesticides, urban soil waste, smelting of ores and parent materials (Mahar et al., 2015). Apart from these sources, there are still many major sources that release heavy metals in huge amounts (Figure 1). Heavy metal pollution in land and water resources has an extensive deleterious effect on the ecosystem and food web (Gaur et al., 2004). Some of the heavy metals are rapidly absorbed. Therefore, they have a huge impact on animal health. The toxicity of heavy metals is dose-dependent. Therefore as the in vivo concentration of heavy metal increases, the toxicity to vital organs increases. Heavy metal toxicity has been implicated as a causative factor for serious disease conditions such as Alzheimer's disease, other mutagenic diseases, and cancer (Dorne et al., 2011). Some harmful effects of heavy metals on human health are enlisted in Table 1.

Unlike organic substances, heavy metals cannot be degraded and accumulate in the environment for a long time. Conventional methods for metal removal are costly. It is difficult to control due to pollutant migration (Tangahu et al., 2011). Many techniques such as microbial-remediation, physio-chemical sorption and nano-particle remediation help to accumulate heavy metals efficiently. However, phytoremediation is an economical and effective alternative to these techniques. These techniques

*Author for correspondence: Pushpa Chaudhary Tomar, Department of Biotechnology, Faculty of Engineering \& Technology, Manav Rachna International Institute Research and Studies, 121001 (Faridabad) India. Email - pushpa.fet@mriu.edu.in 
are widely used in the sorption of not only heavy metals but also many other pollutants such as dyes, pesticides, and herbicides. The accumulation of heavy metals can be carried out by agro-waste materials, micro-organisms and plants, also known as phytoremediation (Panchal, 2020; Dixit et al., 2015). Phytoremediation by algae is another evolving strategy to accumulate heavy metals from contaminated water bodies. It is found that some algae contain phytochelatin and metallothionein that made complex with heavy metals and then translocate them to vacuoles. Other techniques involve so many processes to remove heavy metals such as sedimentation, flocculation, complexation, cation and anion exchange, precipitation and microbial activity but the accumulation of heavy metals can be done directly by algae. So, the degradation of heavy metals via algae is another way to treat contaminated soil and water bodies (Chekrounand Baghour, 2015).

Plants accumulate heavy metals from the contaminated land. Nowadays, phytoremediation has thus gained importance for remediation of soil and water pollution due to its sustainability and cost-effectiveness (Sarwar et al., 2017; PazFerreiro et al., 2014; Pandey et al., 2015). Phytoremediation occurs through many different mechanisms such as phytoextraction, phytotransformation, phytostabilisation, phytodegradation, rhizofiltration, phytovolatilisation, and hydraulic control (Ghosh and Manchanda, 2019). The present review presents the latest developments in the field of phytoremediation of heavy metals.

\section{Mechanisms of phytoremediation}

Phytoremediation is an in-situ solar energy-driven remediation technology. Plants take up metals leading to their immobilisation and hence preventing their transport. It has been reported that the capability of phytoaccumulation of contaminants is higher in tropical regions because of their high prevailing climate factors that favour plant growth and induces microbial activity (Etim et al., 2012). The properties of soil such as soil texture, soil $\mathrm{pH}$, soil organic matter and redox potential play a key role in the accumulation of heavy metals from contaminated land (Laghlimi et al., 2015; Yobouet et al., 2010). The bioavailability of contaminants is another factor in phytoremediation. At low soil $\mathrm{pH}$, the accumulation and mobility of metals cations increases. However, in alkaline soil $\mathrm{pH}$ condition, these metals are present in the form of metal oxide. As a result, the mobility of metals gets decreased (Semple et al., 2003).

Plant enzymes and rhizosphere microbiota help to modify the soil properties. Clayey soil benefits the process of phytoremediation of heavy metals since it reduces the phytotoxicity of the heavy metals by named metal-organic complexation (Elekes et al., 2014; Brown et al.,2003; Sherene et al., 2010; Sing et al., 2013). The phytoremediation is accomplished through different mechanisms such as phytoextraction, phytotransformation, phytostabilisation, phytodegradation, rhizofiltration, phytovolatilisation, and hydraulic control (Kong et al., 2017) (Figure 2).

Table 1. Permissible limits and toxic effects of heavy metals.

\begin{tabular}{cccc}
\hline $\begin{array}{c}\text { Heavy } \\
\text { Metals }\end{array}$ & $\begin{array}{c}\text { Permissible } \\
\text { Limits } \\
(\mathbf{p p m})\end{array}$ & \multicolumn{1}{c}{ Toxic Effect } & References \\
\hline $\mathrm{Ag}$ & 0.10 & Throat and lung infection, stomach pain & Hall et al., 1992 \\
\hline $\mathrm{As}$ & 0.01 & Affect ATP synthesis and phosphorylation & Tripathi et al., 2007 \\
\hline $\mathrm{Hg}$ & 2.0 & Brain damage, hair loss, autoimmune diseases & $\begin{array}{c}\text { Neustadt } \text { et al., 2007; } \\
\text { Gulati } \text { et al., 2010 }\end{array}$ \\
\hline $\mathrm{Zn}$ & 0.5 & Fatigue & Salzman et al., 2002 \\
\hline $\mathrm{Pb}$ & 15 & $\begin{array}{l}\text { Reduction in intelligence, risk of cardiovascular } \\
\text { diseases }\end{array}$ & $\begin{array}{c}\text { Salem } \text { et al., 2000; } \\
\text { Padmavathiamma } \text { et al., 2007 }\end{array}$ \\
\hline $\mathrm{Cu}$ & 1.3 & Intestine irritation & Wuana et al., 2011 \\
\hline $\mathrm{Ba}$ & 2.0 & Respiratory failure, gastrointestinal dysfunction & Jacobs et al., 2002 \\
\hline $\mathrm{Ni}$ & 0.2 & Lung cancer, infertility and genotoxicity & Das et al., 2008
\end{tabular}




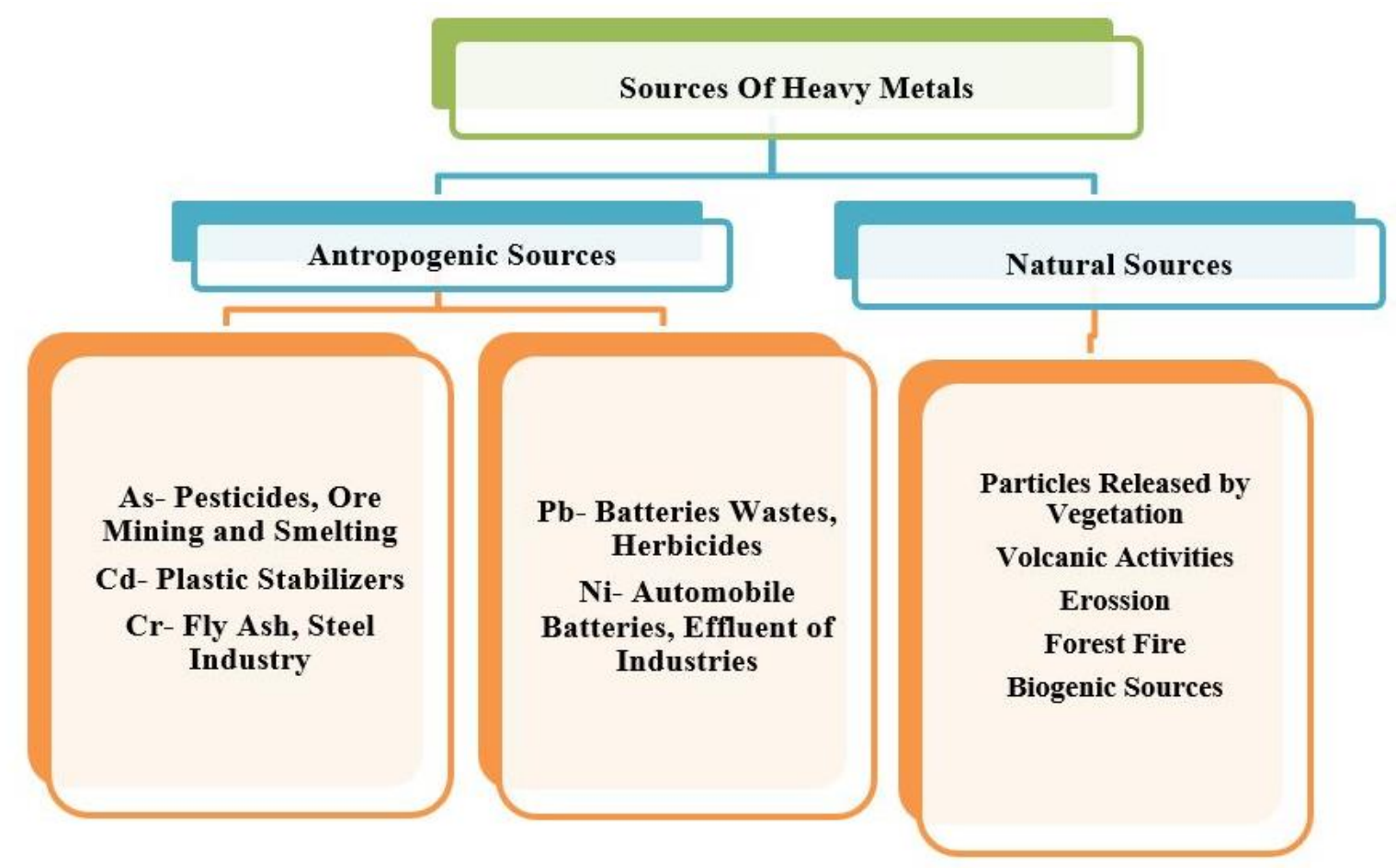

Figure 1. Representation of sources of heavy metals.

\section{Phytoextraction}

Phytoextraction also has known as phytoaccumulation where heavy metals are taken up directly by the plants (heavy metals $\mathrm{Pb}, \mathrm{As}, \mathrm{Zn}$ and $\mathrm{Cr}$ ). Heavy metals are stored in harvestable parts (root, shoot, stem, and leaf) of the plant (Kumar et al., 1995). However, all plants are known to take up contaminants to some extent some of the plant species have been now recognised as hyperaccumulators. These plants accumulate heavy metals in their parts and yet unaffected by those toxic effects of the accumulated heavy metals. The plants get adapted to survive in the highly contaminated matrix (soil and water) (Suman et al., 2018). Most of the hyperaccumulator plants belong to Tiliaceae, Proteaceae, Rubiaceae and Brassicaceae families. These hyperaccumulator plants varieties have been reported to accumulate different metals like $\mathrm{Zn}$, $\mathrm{Cd}$ and $\mathrm{Ni}$ (Milner et al., 2008). Some the important factors in phytoextraction are (i) plants variety, (ii) plant growth rate -higher the rate of growth higher is accumulation, (iii) to be applied in situ as a remediation tool the plant needs to be distributed widely, (iv) the site for hyperaccumulator plants should be chosen in such a way that they are separated from the fodder plants for herbivores so as not to disturb the food chain (Sarwar et al., 2017).

\section{Phytotransformation}

Phytodegradation is another common name of phytotransformation. Plants take up the heavy metals through the cortical tissue of root due to their similarity with some essential micro-nutrient and use the apoplastic and symbiotic pathway to reach xylem. These heavy metals also increase water stress in plants by decreasing the transpiration rate and stomatal conductance (Sarwar et al., 2017). So, in phytotransformation plants can degrade toxic molecules and then convert into the non-toxic molecule, and this made possible by different plant enzymes and enzyme co-factors (Sharma and Sachdeva, 2013). Different plant enzymes such as nitroreductase and nitrilase actively participate in the breakdown of toxic compounds. It also enhances microbial degradation in the rhizosphere (Leguizamo et al., 2016). There are some species of plants like Eurasian watermilfoil and bydrilla that helps to treat polluted water bodies (McCutcheon and Schnoor, 2004). Dec and Bollag (1994) observed that plant species could degrade aromatic rings even in the absence of micro-organism. However, this mechanism is not effective for heavy metal remediation. 


\section{Phytostabilisation}

It is also known as phytoimmobilization because, in this technique, plants can reduce the mobility of heavy metals. So, it could not reach the groundwater. This process takes place by the root zone of the plants. As the phytostabilisation technique restricts the heavy metals to move from soil to groundwater, it should be monitored regularly to get an efficient result. But this technique is not enough to restrict the mobilisation of heavy metals into the water. Other techniques should also be concerned (Erakhrumen and Agbontalor, 2007).

\section{Rhizofiltration}

The free-living rhizobacteria enter into roots and play different roles (i) helps to produce several hormones that stimulate plant growth (ii) release antibiotics so that plants could not be affected by diseases (Gupta et al., 2017). Sobariu et al. (2017) reported that Azobacter microbial population increase the growth of Lepidium sativa plant in the presence of toxic heavy metals. The plant root length was increased by $22 \%$, stem length increased by $34 \%$, and dry biomass was observed $53 \%$. The plants are first grown in greenhouse nursery. After a satisfactory growth of plant roots, the plants are harvested and planted on the contaminated sites. Then these plants start to accumulate heavy metals from contaminated wastewater and reached saturation point, and after that again, these plants are harvested from the sites. Many plants such as tobacco, rye, spinach and Indian mustard have excellent capabilities to accumulate lead from contaminated water (Lebrun, 2001). The $\mathrm{pH}$ of water is an important factor in this process and is needed to be monitored regularly. Diazotrophic bacteria also increase the efficiency of phytoremediation. These bacteria convert metal to more bioavailable form by process of a redox reaction, leaching, and methylation. Diazotrophs also promotes the growth of plants by fixing nitrogen phytochrome synthesis and phosphorous solubilisation (Ullah et al., 2015).

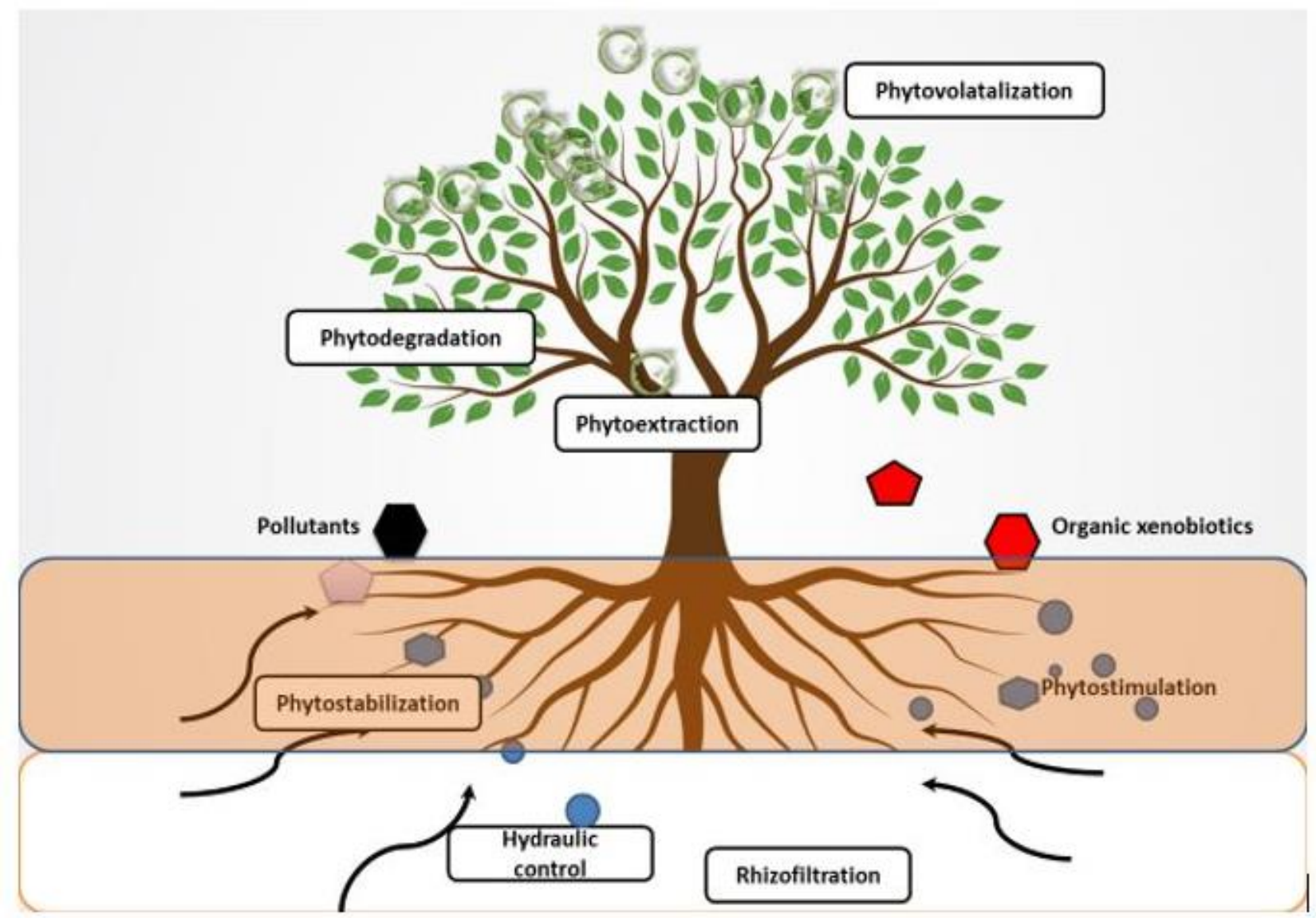

Figure 2. Mechanism of phytoremediation. 


\section{Phytovolatilization}

Phytovolatilization is a subprocess of phytoremediation. In this process, plants after accumulating the heavy metals from the contaminated matrix and release them in the form of volatile compounds into the atmosphere through transpiration. Usually, this process takes place when plants are in their growing stage and take water and organic compounds for the same. During this process, plants convert high toxic metals into less toxic metallic compounds then release them into the environment. Some heavy metals like mercury, selenium and volatile hydrocarbons are occurring through phytovolatilisation (Kamusoko et al., 2017). Dushenkov (2003) reported in their studies that plant species such as N. tabacum, Tritium and liriodendron tulipifera effectively absorb and volatilised $\mathrm{Hg}$ from highly contaminated soil.

\section{Hydraulic control}

In this process, the roots of the plants function as a pump drawing contaminated groundwater and prevent it from mixing with clean water sources (Muthusaravanan et al., 2018). There are lots of plant species that show effectual results in the removal of heavy metals such as Populus species (Hirsh et al., 2003), Salix species (Negri et al., 2004) and Eucalyptus species (Ferro et al., 2003).

\section{Advanced techniques for phytoremediation}

\section{Metal hyper-accumulator plant species}

Several varieties of plants have been reported to be accumulators of heavy metals from contaminated soil (Hao et al., 2014). Many species of aquatic plants help in up taking of heavy metals from contaminated water (Rahman and Hasegawa, 2011). Some of the excellent examples are water hyacinth, duckweed, water fern, watercresses, and water cabbage. Young trees are known to accumulate heavy metals more rapidly as compared to the adult trees. Alvardo et al. (2008) studied that phytoremediation of Arsenic (As) using E. Crassipes species of plant is capable of accumulating up to $600 \mathrm{mg} / \mathrm{ha} / \mathrm{d}$ from contaminated soil. Solanum photeinocarpum shows effective results in uptake of Cadmium metal (71\%) (Zhang et al., 2011). Barbosa et al. (2015) found that Arundodonax L. species of plant can accumulate $\mathrm{Zn}$ metal up to $60 \%$ from contaminated soil. Altinozlu et al. (2012) reported that Isatis pinnatilota could remove inactive $\mathrm{Ni}$ from the soil very effectively up to $1441 \mathrm{mg} / \mathrm{kg}$. Sukumaran et al. (2013) studied phytoremediation of lead $(\mathrm{Pb})$, copper $(\mathrm{Cu})$, arsenic $(\mathrm{As})$ and cadmium (Cd). These metals were accumulated by four different types of plant species Typhalatifolia, Eichhornia crassipes, Salviniamolesta, and Pistiastratiotes.

All types of heavy metal accumulation were observed in both the root and leaf of a plant. Lead and Arsenic highly accumulated by Eichhornia crassipes species. But copper and cadmium were removed prominently by Typhalatifolia species. Ahmadpour et al. (2014) took four plants that are belonging to different species Jatropha curcas, Acacia, Dyera costulata and Hopea odorata in his study to remediate copper metal. Hopea odorata had the greatest potential for remediation of copper contamination metal. Garcia-Salgado et al. (2012) find out that Corrigiola telephifollia was able to accumulate arsenic metal from contaminated soil (up to $2110 \mathrm{mg} / \mathrm{kg}$. Hydrilla verticillata plant was used to uptake Cadmium metal (He et al., 2016). Pandharipande et al. (2016) study two aquatic plant species E. crassipes and Azolla to accumulate copper and chromium. Azolla was able to uptake both the metals (29\% and 14\% respectively). The accumulation was found to increase with time of exposure. E. crassipes uptake both metals up to $13 \%$ and $71 \%$ respectively. Niazi et al. (2017) observed that the addition of phosphate in the root of Brassica napus and Brassica juncea lead to an increase in the rate of accumulation of metals and made the plant more metal tolerant. In this study, both of these species were used for remediation of Arsenic metal from the contaminated soil. Brassica could accumulate as metal up to $75 \%$ (Table 2).

Ali et al. (2012) study the uptake of $\mathrm{Cd}, \mathrm{Pb}, \mathrm{Cu}$, and $\mathrm{Zn}$ by $\mathrm{T}$. alexandrinum plant species. The maximum removal was observed in plant roots and also in leaves, and stem in decreasing order. Zinc was the highest accumulated heavy metal in the study. Mojiri (2012) treated heavy metal contamination from municipal wastewater by using Typhadomingensis plant species. In 2005, Yanqun studied the phytoremediation capacity of 129 species of plants belonging to 50 families for 
his experiment. All the plant species were grown on the lead-zinc mining area in Yunnan (China), from which 16 species of plants were chosen as a best- performing specimens. Out of those 16 species, 10 species were found to accumulate $\mathrm{Pb}$, 4 species $\mathrm{Zn}$ and 5 species for $\mathrm{Cd}$. Corydalis pterygopetala was fud to accumulate all of the metals under the study. Turgut et al. (2001) worked on synthetic chelators to investigate their ability in phytoremediation of $\mathrm{Cd}, \mathrm{Ni}$, and $\mathrm{Cr}$ contaminated soil. Ethylene diamine tetraacetic acid (EDTA) and Hyrody ethylene diamine tetraacetic acid (HEDTA) were applied to the soil at a different dosage. After all the experiments it was concluded that EDTA increases $59 \mu \mathrm{g} \backslash$ plant and $42 \mu \mathrm{g} \backslash$ plant accumulation.

Table 2. Plant species reported for heavy metal sequestration.

\begin{tabular}{|c|c|c|}
\hline Plants & $\begin{array}{l}\text { Heavy metal } \\
\text { sequestration }\end{array}$ & Reference \\
\hline Asteraceae & $\mathrm{Ni}$ & Slatter et al., 1998 \\
\hline Brassicaceae & $\mathrm{Zn}, \mathrm{Cd}, \mathrm{As}$ & $\begin{array}{l}\text { Zhang et al., 2017; } \\
\text { Niaziet al., } 2017\end{array}$ \\
\hline Violaceae & $\mathrm{Pb}, \mathrm{Zn}, \mathrm{Cd}$ & Zhuang et al., 2005 \\
\hline Crassulaceae & $\mathrm{Pb}$ & Chen et al., 2013 \\
\hline Poaceae & $\mathrm{Cr}$ & Nalla et al., 2012 \\
\hline Fabaceae & Se & Alford et al., 2012 \\
\hline Acanthus ilicifolius L. & $\mathrm{Cd}$ & Shackira and Puthur, 2017 \\
\hline E. crassipes & $\mathrm{As}, \mathrm{Cu}$ & $\begin{array}{l}\text { Alvardo et al., 2008;Ebel } \text { et al., } \\
\text { 2007; Pandharipande et al., } 2016\end{array}$ \\
\hline Solanumphoteinocarpum & $\mathrm{Cd}$ & Zhang et al., 2011 \\
\hline Arundodonax L. & $\mathrm{Zn}$ & Barbosa et al., 2015 \\
\hline Isatispinnatilota & $\mathrm{Ni}$ & Altinozlu et al., 2012 \\
\hline Eichhornia sp. & $\mathrm{Pb}$ & Sukumaran et al., 2013 \\
\hline Typha sp. & $\mathrm{As}, \mathrm{Cu}, \mathrm{Cd}$ & Sukumaran et al., 2013 \\
\hline Hopeaodorata (Merwansiput jantum) & $\mathrm{Cu}$ & Ahmadpour et al., 2014 \\
\hline Corrigiolatelephifollia & As & Garcia-Salgado et al., 2012 \\
\hline Hydrillaverticillata & As & He et al., 2016 \\
\hline Azolla & $\mathrm{Cr}$ & $\begin{array}{l}\text { Pandharipande et al., 2016; } \\
\text { Rai and Tripathi, } 2009\end{array}$ \\
\hline L. gibba & As & Mkandawire et al., 2005 \\
\hline N. microphyllum & As & Robinson et al., 2006 \\
\hline Pterisvittata & As & Sakakibaraet al., 2010 \\
\hline Liriodendron tulipifer & Methyl-Hg & Greipsson et al., 2011 \\
\hline Trifoliumalexandrinum & $\mathrm{Cd}, \mathrm{Pb}, \mathrm{Cu}, \mathrm{Zn}$ & Ali et al., 2012 \\
\hline Typhadomingensis & $\mathrm{Fe}, \mathrm{Mn}, \mathrm{Zn}, \mathrm{Ni}, \mathrm{Cd}$ & Mojiri et al., 2012 \\
\hline Corydalis pterygopetala & $\mathrm{Zn}, \mathrm{Cd}$ & Yanqun et al., 2005 \\
\hline Sonchusasper & $\mathrm{Pb}, \mathrm{Zn}$ & Yanqun et al., 2005 \\
\hline Helianthus annuus & $\mathrm{Cd}, \mathrm{Cr}, \mathrm{Ni}$ & Turgut et al., 2001 \\
\hline Thlaspicaerulescens & $\mathrm{Zn}$ & Lasatet al., 2000 \\
\hline Salix schwerinii & $\begin{array}{c}\mathrm{Cr}, \mathrm{Zn}, \mathrm{Cu}, \mathrm{Ni} \text {, Petroleum } \\
\text { hydrocarbons }\end{array}$ & Salam et al., 2016 \\
\hline Jatrophacurcas & $\mathrm{Cd}, \mathrm{Cr}, \mathrm{Co}, \mathrm{Ni}$ & Luhach and Chaudhry, 2012 \\
\hline $\begin{array}{l}\text { Tagetespatula } \\
\text { Brassica juncea }\end{array}$ & $\mathrm{Cr}, \mathrm{Pb}, \mathrm{Co}, \mathrm{Zn}$ & Choudhary et al., 2016 \\
\hline Arbuscular mycorrbiza & $\mathrm{Zn}, \mathrm{Cu}, \mathrm{Fe}, \mathrm{Mn}$ & Khan et al., 2014 \\
\hline $\begin{array}{l}\text { Pterisvittata } \\
\text { Pteris critical }\end{array}$ & $\mathrm{As}, \mathrm{Pb}$ & Sun et al., 2014 \\
\hline Lavandula vera $L$ & $\mathrm{~Pb}, \mathrm{Zn}, \mathrm{Cd}$ & Angelova et al., 2015 \\
\hline $\begin{array}{l}\text { Glyceria maxima Phragmitesaustralis typhalatifolia } \\
\text { Phalarisarundincea }\end{array}$ & $\mathrm{Zn}, \mathrm{Fe}, \mathrm{Mn}, \mathrm{Ni}, \mathrm{Cu}$ & Parzych et al., 2015 \\
\hline
\end{tabular}




\begin{tabular}{|c|c|c|}
\hline $\begin{array}{l}\text { Mixture of Typhaangustifolia sp. and } \\
\text { Limnocharisflava sp. }\end{array}$ & 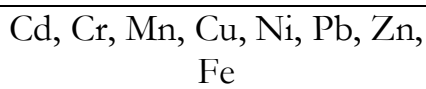 & Syukor et al., 2016 \\
\hline Trapanatans & $\mathrm{Cd}, \mathrm{Cu}$ & Bauddh et al., 2015 \\
\hline Elodea canadensis & $\begin{array}{c}\mathrm{Fe}, \mathrm{Co}, \mathrm{Cd}, \mathrm{Cu}, \mathrm{Ni}, \mathrm{Mn}, \mathrm{Cr} \text {, } \\
\text { Mo, } \mathrm{Zn}, \mathrm{Se}\end{array}$ & Miranda et al., 2014 \\
\hline $\begin{array}{l}\text { Callitrichestagnalis } \\
\text { Potannogetonnatans } \\
\text { Pectinatus L. }\end{array}$ & $\mathrm{U}$ & Pratas et al., 2014 \\
\hline $\begin{array}{l}\text { Phragmitescummunis } \\
\text { Typha angustifolia } \\
\text { Cyperus esculentus }\end{array}$ & $\begin{array}{c}\mathrm{Cd}, \mathrm{Cr}, \mathrm{Cu}, \mathrm{Mn}, \mathrm{Fe}, \mathrm{Ni}, \mathrm{Pb} \text {, } \\
\mathrm{Zn}\end{array}$ & Chandra et al., 2011 \\
\hline
\end{tabular}

In 2000, Lasat used Thlaspi caerulescens plant species to accumulate $\mathrm{Zn}$ from contaminated sites. Thlaspi caerulescens accumulate 3\% dry zinc in their shoot zone, but radiotracer flux techniques were used to tract accumulation of zinc in the shoot and root of the plant. The accumulation of zinc was very high in the shoot area without any associated toxicity symptom. Salam et al. (2016) selected Salix schwerinii plant species to accumulate $\mathrm{Cr}, \mathrm{Zn}, \mathrm{Cu}$, $\mathrm{Ni}$ and petroleum hydrocarbons. All the experiments were performed in pots, to estimate accumulation and plant growth performance under the high level of heavy metals. The soil used in the pot experiment was collected from the landfill area in Finland. The whole experiment was conducted in141 days at 4 and $6 \mathrm{pH}$. The maximum accumulation of heavy metals was observed at $\mathrm{pH}$ 6. The total amount of $\mathrm{Cr}, \mathrm{Zn}, \mathrm{Cu}$ and $\mathrm{Ni}$ was $250.45 \mathrm{mg} \backslash \mathrm{kg}, 1616.59 \mathrm{mg} \backslash \mathrm{kg}, 223.74$ and $75.90 \mathrm{mg} \backslash \mathrm{kg}$. The whole study investigates that Salix schwerinii has great potential to accumulate heavy metals from contaminated soil.

Luhach and Chaudhry (2012) accumulate heavy metals from oily sludge of petroleum refinery by Jatropha curcas plant species. All the experiments were planned to perform in growth media with sludge at six levels. The growth of Jatropha seeds was controlled in the first three experiments. The maximum plant biomass was observed at S1 and S2 treatment, whereas maximum multiple heavy metal removal was observed at S2 and S3 treatment. From the oily sludge maximum removal was observed of cadmium, followed by $\mathrm{Cr}, \mathrm{Cu}$ and Ni. Choudhury et al. (2015) used Mustard and Marigold plants to accumulate heavy metals from Buriganga Riverbed sediment. Buriganga riverbed was contaminated with $\mathrm{Cr}, \mathrm{Pb}, \mathrm{Cu}$ and $\mathrm{Zn}$. The maximum removal of all the heavy metals by the mustard plant was observed 102.6, 28.9, 53 and $1861.5 \mathrm{mg} \backslash \mathrm{kg}$ respectively whereas Marigold plant accumulates all the heavy metals up to $90 \%$. Khan et al. (2014) used AM fungi in the accumulation of heavy metals of $\mathrm{Zn}, \mathrm{Cu}, \mathrm{Fe}$ and $\mathrm{Mn}$ and its effect on the yield of wheat crop. All the experiments were conducted in pots by $\mathrm{CR}$ design with four replications during 2012-13. It was observed from this study that the potential of phytoremediation of contaminated soil could be improved by the inoculation of crops with $\mathrm{AM}$ fungi. Angelova et al. (2013) conduct the field study to evaluate the efficiency of Lavandula vera $L$. in the accumulation of heavy metals from contaminated soil. The maximum accumulation was observed at the upper part of the plant that is stem, leaves and petals without harming the quantity and quality of the essential oil. Parzych et al. (2015) used four aquatic plant species that were Glyceria maxima, Phragmites australis, Typhalatifolia and Phalaris arundincea to accumulated different heavy metals ( $\mathrm{Zn}, \mathrm{Fe}, \mathrm{Mn}, \mathrm{Ni}$ and $\mathrm{Cu}$ ). T. latifolia maximum removed $\mathrm{Zn}$ and $\mathrm{Ni}$ whereas $G$. maxima highly accumulate $\mathrm{Mn}$ and $\mathrm{Fe}$ that observed in rhizomes of the plant. P. australis and T. latifolia plant uptakes $\mathrm{Mn}$ in their leaves at high concentration.

Syukor et al. (2016) focused on investigating the improvement in the conventional oxidation process integrated by aquatic plant species. The experiment was continued to $12-13$ days. The maximum removal of $\mathrm{Cu} 79.07 \%, \mathrm{Mg} 68 \%, \mathrm{Cd}$ $61.07 \%$, Cr $69.17 \%$, Ni $74.87 \%$, Fe $81.17 \%, \mathrm{~Pb}$ $62.07 \%$ and $\mathrm{Zn} \mathrm{63 \%}$ was observed. Miranda et al. (2014) used duckweed, elodea and water clover plant species to accumulate selenium from wastewater and also focused on producing biofuel from that waste. After the accumulation of selenium, some amount of bio-gas, bio-solid and 
pyrolysis of these plants produce a large straight chain of c14-c20 alkanes that can directly use as diesel fuel. Chandra et al. (2011) used three plant species $P$. cummunis, T. angustifolia, and C. esculentus to accumulate $\mathrm{Cd}, \mathrm{Cr}, \mathrm{Cu}, \mathrm{Mn}, \mathrm{Fe}, \mathrm{Ni}, \mathrm{Pb}$ and $\mathrm{Zn}$. $P$. cummunis were shoot accumulator plants whereas $T$. angustifolia was root accumulator plants. C. esculentus accumulate all the heavy metals by their root zone except $\mathrm{Mn}$ and Fe that was uptake by shoot and found in leaves. From this whole study, it was analysed that $P$. cummunis and $T$. angustifolia has great potential to accumulate heavy metals as compared to $C$. esculentus. Rodríguez et al. in 2018 compared the heavy metal accumulation by two plant species B. juncea and $S$. lycopersicum. It was observed that $B$. juncea was absorbed heavy metals in their root and shoot from that contaminated soil.

\section{Plant-microbe interactions for enhancing phytoremediation}

In recent years, scientists have focussed on discovering and establishing the diverse mechanisms of phytoremediation as detailed in the previous sections. Exciting research is being carried out to establish new plant-microbe interactions for enhancing phytoremediation of heavy metal contaminated sites (Saxena et al., 2019). The plant growth-promoting rhizobacteria have been reported to improve host plant growth at metal-contaminated sites through the production of different growth hormones (auxins, cytokinins, gibberellins, ethylene, etc.) Arbuscular mycorrhizal fungi have been identified to protect the host plant from heavy metal toxicity and help in the phytoremediation process (Meier et al., 2012; Khan et al., 2014). Endophytes that reside in the inner tissue of the host plant and help in plant growth. It is highly tolerant of high heavy metal concentration and thereby helps in phytoremediation (Luo et al., 2011; Ma et al., 2015).

\section{Enhancing the bioavailability of metals for uptake by plants}

Several technologies have been developed that assist the plants in increasing phytoremediation or by protecting the plants from the toxic effects of the heavy metals. Vermicomposting is one such technique used to increase the phytoremediation process because earthworms are used from the ancient period in the decomposition of heavy metals from soil. By using these two processes (phytoremediation and vermicomposting) efficient results could be obtained. Naturally occurring species such as aromatic plants and energy crops can grow in such contaminated sites that accumulate heavy metals very well. In order to enhance the metal uptake by plants, strategies such as the addition of chelating agents such as ethylenediaminetetraacetic acid (EDTA), ethylenediamine-N, N'-disuccinic acid (EDDS), humic substances have been successful (Luo et al., 2018).

\section{Genetically engineered hyper-accumulator plant}

Genetic engineering of plant species with an objective to create hyperaccumulators for phytoremediation is an attractive strategy. Several researchers have successfully applied genetic engineering for overexpression of genes responsible for phytoremediation. However, these experiments are performed only on a small scale and tested to get desirable results (Koźmińska et al., 2018). Table 3 summarises the genetically engineered plant species used for phytoremediation.

Pan et al. (1994) cloned the MT-1 gene from Mus musculus into Nicotiana tabacum plant to improve cadmium resistance. This genetically engineered plant could effectively remove shows very good results that were up to $10-200 \mu \mathrm{m}$. Similarly, modification of Brassica napus L. and Nicotiana tabacum plant by MT-2 gene obtained from Saccharomyces cerevisiae led to the improvement in their tolerance (KaÈrenlampi et al., 2000).

Genetic manipulation also showed a promising technique to enhance phytoremediation. The aim is to introduce metal tolerant genes into the plant tissues for a hyperaccumulation of heavy metals from highly contaminated sites (Sarwar et al., 2017; Chandra et al., 2015). Also, genetically modified bacteria in symbiotic plant-associated microbes relationship help in phytoremediation (Ullah et al., 2015; Huang et al., 2016). However, a major impediment in the studies involving genetically modified organisms is restrictions on large-scale field trials. This needs to be addressed using systematic technological innovations that ensure the safety of 
the intervention in the field and also by changing the outlook of the policy-makers. However, comprehensive risk assessment studies need to be undertaken before this technique can be used effectively.

Table 3. Hyperaccumulator transgene types and host plant species.

\begin{tabular}{|c|c|c|c|c|}
\hline $\begin{array}{l}\text { Transferred } \\
\text { genes }\end{array}$ & Function of the transgene & Target plant & $\begin{array}{l}\text { Heavy } \\
\text { metal }\end{array}$ & Reference \\
\hline NRAMP1 & $\begin{array}{l}\text { Spanning protein: Fe transporter in } \\
\text { bacteria, fungi, animals and plants }\end{array}$ & A. Thaliana & As, Cd, Fe & Tiwari et al., 2014 \\
\hline$\hat{\mathbf{y}}-\mathbf{E C S}$ & $\begin{array}{l}\text { 1) Key enzyme GSH pathway. } \\
\text { Overexpression of } \hat{y} \text {-ECS in E.coli } \\
\text { increase Cd tolerance and } \\
\text { accumulation }\end{array}$ & $\begin{array}{l}\text { P. tremula } \\
\text { P. alba }\end{array}$ & $\mathrm{Cd}$ & He et al., 2015 \\
\hline NcZNT1 & 1) ZIP family transporter of $\mathrm{Zn}$ & A. thaliana & $\mathrm{Zn}$ & Milner et al., 2012 \\
\hline $\begin{array}{l}\text { AtABCC1 } \\
\text { AtABCC2 }\end{array}$ & $\begin{array}{l}\text { 1) ZIP family transporter } \\
\text { 2) Accumulation of Cd } \\
\text { 3) Double knockout of AtABCC1 } \\
\text { and AtABCC } 2 \text { enhance tolerance and } \\
\text { accumulation of } \mathrm{Hg}\end{array}$ & A. thaliana & $\mathrm{Cd}, \mathrm{Hg}$ & Park et al., 2012 \\
\hline SPDS1 & $\begin{array}{l}\text { 1) Used to encode a functional } \\
\text { protein by complementation of the } \\
\text { spe3 yeast mutant that lacks SPDS } \\
\text { 2) Increased abiotic stress of plants } \\
\text { and also produced transgenic fruits }\end{array}$ & Pyruscommunis & $\mathrm{Cu}$ & Wen et al., 2008 \\
\hline EhMT1 & $\begin{array}{l}\text { 1) EhMT1 overexpression led to } \mathrm{Cu} \\
\text { accumulation in roots }\end{array}$ & N. tabacum & $\mathrm{Cu}$ & Xia et al., 2012 \\
\hline SPMT1 & $\begin{array}{l}\text { 1) SPMT1 similar to MT proteins } \\
\text { hyperaccumulation of Cd in leaves of } \\
\text { Sedum plumbizincicola }\end{array}$ & $\begin{array}{l}\text { Sedum } \\
\text { plumbizincicola }\end{array}$ & $\mathrm{Cd}$ & Peng et al., 2017 \\
\hline MT-1 & 1) Induction by metal ion binding & $\begin{array}{l}\text { Nicotiana } \\
\text { tabacum L. }\end{array}$ & $\mathrm{Cd}$ & Pan et al., 1994 \\
\hline MT-2 & $\begin{array}{l}\text { 1) Human metallothionein - } 2 \text { gene } \\
\text { 2) Increased accumulation of } \mathrm{Cd}\end{array}$ & $\begin{array}{l}\text { Brassica Napus } \\
\text { L. } \\
\text { Nicotiana } \\
\text { tabacum }\end{array}$ & $\mathrm{Cd}$ & $\begin{array}{c}\text { Misra and } \\
\text { Gedamu, } 1989\end{array}$ \\
\hline
\end{tabular}

\section{CONCLUSION}

Phytoremediation is a commercially viable and promising technology that helps to accumulate heavy metals from contaminated land and water bodies. This solar-driven technique does not lead to the production of sludge; it doesn't lead to environmental disturbance and is cost-effective, making it an attractive technology to use. Although phytoremediation has lots of advantages and it helps to reduce soil pollution caused by metalloids. However, the in-situ effectiveness of phytoremediation is heavily dependent on several factors like (i) climate of the region (ii) soil type (iii) plant capability to utilise metals. Therefore field trials are required to improve the accuracy of predictive models. Naturally occurring plants have very limited maintenance requirements and a low-cost process. In conclusion, it needs to be stressed that non-edible plants should be used to avoid bioaccumulation and biomagnification. Phytomining process can be implemented for the 
recovery of the heavy metals by incinerating the metal accumulator crops. Large scale application of various phytoremediation techniques such as phytotransformation, phytoextraction, phytovolatilisation, and phytovolatilisation, etc. will be an excellent sustainable method for recycling and reusing of heavy metals to keep the environment safe, green, and resourceful for future generations.

\section{REFERENCES}

Ahmadpour, P., Ahmadpour, F., Sadeghi, S., Tayefeh, F. H., Soleimani, M., \& Abdu, A. B. 2014. Evaluation of four plant species for phytoremediation of copper-contaminated soil. Soil Remediation and Plants: Prospects and Challenges 147.

Alahabadi, A., Ehrampoush, M. H., Miri, M., Ebrahimi Aval, H., Yousefzadeh, S., Ghaffari, H. R., Ahmadi, E., Talebi, P., AbaszadehFathabadi, Z., Babai, F., Nikoonahad, A., Sharafi, K., \& Hosseini-Begharaei, A. 2017. A comparative study on capability of different tree species in accumulating heavy metals from soil and ambient air. Chemosphere 172: 459-467.

Alford, É. R., Pilon-Smits, E. A., Fakra, S. C., \& Paschke, M. W. 2012. Selenium hyperaccumulation by Astragalus Fabaceae does not inhibit root nodule symbiosis. American Journal of Botany 9912: 1930-1941.

Ali, H., Khan, E., \& Sajad, M. A. 2013. Phytoremediation of heavy metals - concepts and applications. Chemosphere 917: 869881.

Ali, H., Naseer, M., \& Sajad, M. A. 2012. Phytoremediation of heavy metals by Trifoliumalexandrinum. International Journal of Environmental Sciences 23: 1459-1469.

Altinözlü, H., Karagöz, A., Polat, T., \& Ünver, İ. 2012. Nickel hyperaccumulation by natural plants in Turkish serpentine soils. Turkish Journal of Botany 363: 269-280.

Alvarado, S., Guédez, M., Lué-Merú, M. P., Nelson, G., Alvaro, A., Jesús, A. C., \& Gyula, Z. 2008. Arsenic removal from waters by bioremediation with the aquatic plants water hyacinth Eichborniacrassipes and lesser duckweed Lemna minor. Bioresource Technology 9917: 8436-8440.

Angelova, V. R., Grekov, D. F., Kisyov, V. K., \& Ivanov, K. I. 2015. Potential of lavender Lavandulavera L. for phytoremediation of soils contaminated with heavy metals. International Journal of Biological, Biomolecular, Agricultural, Food and Biotechnological Engineering 9: 465-472.

Barbosa, B., Boléo, S., Sidella, S., Costa, J., Duarte, M. P., Mendes, B. \& Fernando, A. L. 2015. Phytoremediation of heavy metal-contaminated soils using the perennial energy crops Miscanthus spp. and Arundodonax L. BioEnergy Research 84: 1500-1511.

Brown, S. L., Henry, C. L., Chaney, R., Compton, H., \& DeVolder, P. S. 2003. Using municipal biosolids in combination with other residuals to restore metal-contaminated mining areas. Plant and Soil 2491: 203-215.

Chandra, R., Saxena, G. and Kumar, V., 2015. Phytoremediation of environmental pollutants: an eco-sustainable green technology to environmental management. Advances in Biodegradation and Bioremediation of Industrial Waste, $1 \mathrm{st}$ edn. CRC Press, Taylor \& Francis Group, Boca Raton, pp.1-30.

Chandra, R. \& Yadav, S., 2011. Phytoremediation of Cd, Cr, Cu, $\mathrm{Mn}, \mathrm{Fe}, \mathrm{Ni}, \mathrm{Pb}$ and $\mathrm{Zn}$ from aqueous solution using phragmitescummunis, typhaangustifolia and cyperusesculentus. International Journal of Phytoremediation 136 : 580-591.

Chekroun, K. B. \& Baghour, M., 2013. The role of algae in phytoremediation of heavy metals: a review. Journal of Materials and Environmental Science 46: 873-880.

Chen, B., Ai, W., Gong, H., Gao, X., \& Qiu, B. 2013. Cleaning up of heavy metals-polluted water by a terrestrial hyperaccumulator Sedum alfredii Hance. Frontiers in Biology 86: 599-605.

Choudhury, M. R., Islam, M. S., Ahmed, Z. U., \& Nayar, F. 2016. Phytoremediation of heavy metal contaminated buriganga riverbed sediment by Indian mustard and marigold plants. Environmental Progress and Sustainable Energy 351: 117-124.

Dec, J., \& Bollag, J. M. 1994. Use of plant material for the decontamination of water polluted with phenols. Biotechnology and Bioengineering 449: 1132-1139.

Dixit, R., Malaviya, D., Pandiyan, K., Singh, U. B., Sahu, A., Shukla, R., \& Paul, D. 2015. Bioremediation of heavy metals from soil and aquatic environment: an overview of principles and criteria of fundamental processes. Sustainability 72: 21892212.

Djingova, R., \&Kuleff, I. 2000.Instrumental techniques for trace analysis. In Trace Metals in the Environment Vol. 4. Elsevier. pp. 137-185

Dorne, J. L., Kass, G. E., Bordajandi, L. R., Amzal, B., Bertelsen, U., Castoldi, A. F., Heppner, C., Eskola, M., Fabiansson, S., Ferrari, P., Scaravelli, E., Dogliotti, E., Fuerst, P., Boobis, A. R., \& Verger, P. 2011. Human risk assessment of heavy metals: principles and applications. Metal Ions in Life Sciences 8: 27-60.

Dushenkov, S. 2003. Trends in phytoremediation of radionuclides. Plant and Soil 2491: 167-175.

Ebel, M., Evangelou, M. W., \& Schaeffer, A. 2007. Cyanide phytoremediation by water hyacinths Eichhorniacrassipes. Chemosphere 665:816-823.

Elekes, C. C. 2014. Eco-technological solutions for the remediation of polluted soil and heavy metal recovery. Environmental Risk. Assessment of Soil Contamination, InTech, Rijeka: 309-335.

Erakhrumen, A. A., \& Agbontalor, A. 2007. Phytoremediation: an environmentally sound technology for pollution prevention, control and remediation in developing countries. Educational Research and Review 2(7): 151-156.

Etim, E. E. 2012. Phytoremediation and its mechanisms: a review. International Journal of Environment and Bioenergy 23: 120-136.

Ferro, A., Gefell, M., Kjelgren, R., Lipson, D. S., Zollinger, N., \& Jackson, S. (2003). Maintaining hydraulic control using deep rooted tree systems. In Phytoremediation pp: 125-156. Springer, Berlin, Heidelberg.

García-Salgado, S., García-Casillas, D., Quijano-Nieto, M. A., \& Bonilla-Simón, M. M. 2012. Arsenic and heavy metal uptake and accumulation in native plant species from soils polluted by mining activities. Water, Air, and Soil Pollution 2232:559572 .

Garrido-Rodríguez, B., Fernández-Calviño, D., Munoz, J.N., Arias-Estévez, M., Díaz-Raviña, M., Álvarez-Rodríguez, E., Fernández-Sanjurjo, M.J. \& Núñez-Delgado, A., 2013. pHdependent copper release in acid soils treated with a crushed mussel shell. International Journal of Environmental Science and Technology 105: 983-994.

Gaur, A., \& Adholeya, A. 2004. Prospects of arbuscularmycorrhizal fungi in phytoremediation of heavy metal contaminated soils. Current Science 864: 528-534.

Ghosh, A. \& Manchanda, N., 2019. Phytoremediation of heavy metals from water of Yamuna River by Tagetespatula, Bassicascoparia, Portulacagrandiflora. Asian Plant Research Journal: 1-14. 
Gulati, K., Banerjee, B., Lall, S. B., \& Ray, A. 2010. Effects of diesel exhaust, heavy metals and pesticides on various organ systems: possible mechanisms and strategies for prevention and treatment. Indian Journal of Experimental Biology 487: 710 721.

Gupta, P., \& Diwan, B. 2017. Bacterial exopolysaccharide mediated heavy metal removal: a review on biosynthesis, mechanism and remediation strategies. Biotechnology Reports 13: 58-71.

Hall, H. I., Dhara, V. R., Price-Green, P. A., \& Kaye, W. E. 1994.Surveillance for emergency events involving hazardous substances-United States, 1990-1992. Morbidity and Mortality Weekly Report: CDC Surveillance Summaries: 1-6.

Hao X., Taghavi S., Xie P., Orbach M. J., Alwathnani H. A., Rensing C. \& Wei G. 2014. Phytoremediation of heavy and transition metals aided by legume-rhizobia symbiosis.International Journal of Phytoremediation 162: 179202.

He, J., Li, H., Ma, C., Zhang, Y., Polle, A., Rennenberg, H., Cheng, X., \& Luo, Z. B. 2015. Overexpression of bacterial $\gamma$ glutamylcysteinesynthetase mediates changes in cadmium influx, allocation and detoxification in poplar. New Phytologist 2051: 240-254.

Hirsh, S. R., Compton, H. R., Matey, D. H., Wrobel, J. G., \& Schneider, W. H. 2003. Five-year pilot study: Aberdeen Proving Ground, Maryland. in Phytoremediation: Transformation and control of contaminants. Ed. McCutcheon S. C. and Schnoor J. L., pp: 635-659, Hoboken: Wiley.

Huang, J., Liu, Z., Li, S., Xu, B., Gong, Y., Yang, Y., Sun, H. 2016 Isolation and engineering of plant growth promoting rhizobacteria Pseudomonas aeruginosa for enhanced cadmium bioremediation. The Journal of General and Applied Microbiology 62: 258-265

Jacobs, I. A., Taddeo, J., Kelly, K., \& Valenziano, C. 2002. Poisoning as a result of barium styphnate explosion. American Journal of Industrial Medicine 414: 285-288.

KaÈrenlampi, S., Schat, H.,Vangronsveld, J.,Verkleiji. A. C., Van DerLelie, D., Mergeay, M., \& Tervahauta, A. I. 2000. Genetic engineering in the improvement of plants for phytoremediation of metal polluted soil. Environmental Pollution 107: 225-231.

Kamusoko, R., \& Jingura, R. M. 2017. Utility of Jatropha for phytoremediation of heavy metals and emerging contaminants of water resources: a review. CLEAN-Soil, Air, Water 4511: 1700444.

Khan, A., Sharif, M., Ali, A., Shah, S., Mian, I., Wahid, F., Jan, B., Adnan, M., Nawaz, S. \& Ali, N. 2014 Potential of AM fungi in phytoremediation of heavy metals and effect on yield of wheat crop. American Journal of Plant Sciences 5: 1578-1586.

Kong, Z., \& Glick, B. R. 2017. The role of plant growth-promoting bacteria in metal phytoremediation. Advances in Microbial Physiology 71: 97-132.

Koźmińska, A., Wiszniewska, A., Hanus-Fajerska, E., \& Muszyńska, E. 2018. Recent strategies of increasing metal tolerance and phytoremediation potential using genetic transformation of plants. Plant biotechnology Reports 121: 1-14.

Kumar, P. N., Dushenkov, V., Motto, H., \& Raskin, I. 1995. Phytoextraction: the use of plants to remove heavy metals from soils. Environmental Science and Technology 295: 1232 1238.

Laghlimi, M., Baghdad, B., El Hadi, H. \& Bouabdli, A., 2015. Phytoremediation mechanisms of heavy metal contaminated soils: a review. Open Journal of Ecology 58:375388.

Lasat, M. M., Pence, N. S., Garvin, D. F., Ebbs, S. D., \& Kochian, L. V. 2000.Molecular physiology of zinc transport in the $\mathrm{Zn}$ hyperaccumulator Thlaspicaerulescens. Journal of Experimental Botany 51342: 71-79.

Lebrun, M. 2001. Phytoremediation of Toxic Metals: Using Plants to Clean Up the Environment, Edited by I. Raskin and B. Ensley, John Wiley and Sons, Inc., New York, 2000. ISBN 0-471-19254-6; 304 pp. Plant Science 5160: 1073-1075.

Leguizamo, M. A. O., Gómez, W. D. F., \& Sarmiento, M. C. G. 2017. Native herbaceous plant species with potential use in phytoremediation of heavy metals, spotlight on wetlandsa review. Chemosphere 168: 1230-1247.

Luhach, J., \& Chaudhry, S. 2012. Phytoremediation potential of Jatrophacurcas for removal of heavy metals from refinery sludge. International Journal of Science Engineering Research 310: $1-5$.

Li, Y., Luo, J., Yu, J., Xia, L., Zhou, C., Cai, L., \& Ma, X. 2018. Improvement of the phytoremediation efficiency of Neyraudia reynaudiana for lead-zinc mine-contaminated soil under the interactive effect of earthworms and EDTA. Scientific Reports 8(1): 1-10.

Luo, S. L., Chen, L., Chen, J. L., Xiao, X., Xu, T. Y., Wan, Y., Rao, C., Liu, C. B., Liu, Y. T., Lai, C., \& Zeng, G. M., 2011. Analysis and characterisation of cultivable heavy metalresistant bacterial endophytes isolated from $\mathrm{Cd}$ hyperaccumulator Solanum nigrum $\mathrm{L}$. and their potential use for phytoremediation. Chemosphere 85(7): 1130-1138.

Ma, Y., Oliveira, R. S., Nai, F., Rajkumar, M., Luo, Y., Rocha, I., \& Freitas, H., 2015. The hyperaccumulator Sedum plumbizincicola harbors metal-resistant endophytic bacteria that improve its phytoextraction capacity in multi-metal contaminated soil. Journal of Environmental Management 156: 62-69.

Mahar, A., Wang, P., Ali, A., Awasthi, M. K., Lahori, A. H., Wang, Q., Li R \& Zhang, Z. 2016. Challenges and opportunities in the phytoremediation of heavy metals contaminated soils: A review. Ecotoxicology and Environmental Safety 126: 111-121.

McCutcheon, S. C. \& Schnoor, J. L. 2004. Phytoremediation: Transformation and control of contaminants. Environment Science and Pollution Research 11: 40.

Meier, S., Borie F., Bolan, N., Cornejo, P. 2012 Phytoremediation of metal-polluted soils by arbuscularmycorrhizal fungi. Critical Reviews in Environmental Science and Technology 42(7): 741-775.

Milner, M. J., \& Kochian, L. V. 2008. Investigating heavy-metal hyperaccumulation using Thlaspi caerulescens as a model system. Annals of Botany 1021: 3-13.

Milner, M. J., Craft, E., Yamaji, N., Koyama, E., Ma, J. F., \& Kochian, L. V. 2012. Characterisation of the high affinity Zn transporter from Noccaea caerulescens, NcZNT1, and dissection of its promoter for its role in $\mathrm{Zn}$ uptake and hyperaccumulation. New Phytologist 1951: 113-123.

Miranda, A., Muradov, N., Gujar, A., Stevenson, T., Nugegoda, D., Ball, A., \& Mouradov, A. 2014. Application of aquatic plants for the treatment of selenium-rich mining wastewater and production of renewable fuels and petrochemicals. Journal of Sustainable Bioenergy Systems 41: 97-112.

Misra, S., \& Gedamu, L. 1989. Heavy metal tolerant transgenic Brassica napus L. and Nicotiana tabacum L. plants. Theoretical and Applied Genetics 782: 161-168.

Mkandawire, M. \& Dudel, E. G. 2005. Accumulation of arsenic in Lemnagibba $L$. duckweed in tailing waters of two abandoned uranium mining sites in Saxony, Germany. Science of the Total Environment 336(1-3): 81-89.

Mojiri, A. 2012. Phytoremediation of heavy metals from municipal wastewater by Typhadomingensis. African Journal of Microbiology Research 63: 643-647.

Muthusaravanan, S., Sivarajasekar, N., Vivek, J. S., Paramasivan, T., Naushad, M., Prakashmaran, J., Gayathri, V. \& Al-Duaij, O. K., 2018. Phytoremediation of heavy metals: 
mechanisms, methods, and enhancements. Environmental Chemistry Letters 164: 1339-1359.

Nalla, S., Hardaway, C. J. \& Sneddon, J. 2012.Phytoextraction of selected metals by the first and second growth seasons of Spartina alterniflora. Instrumentation Science and Technology 401: 17-28.

Neustadt, J. \&Pieczenik, S. 2007. Patient handout: Toxic metal contamination: mercury. Integrative Medicine-Innovision Communications 6(2): 36.

Niazi, N. K., Bibi, I., Fatimah, A., Shahid, M., Javed, M. T., Wang, H., Ok, Y. S., Bashir, S., Murtaza, B., Saqib, Z. A. \& Shakoor, M. B. 2017. Phosphate-assisted phytoremediation of arsenic by Brassica napus and Brassica juncea: Morphological and physiological response. International Journal of Phytoremediation 197: 670-678.

Padmavathiamma, P. K. \& Li, L. Y. 2007. Phytoremediation technology: hyper-accumulation metals in plants. Water, Air and Soil Pollution 184: 105-126.

Pan, A., Yang, M., Tie, F., Li, L., Chen, Z. \& Ru, B. 1994. Expression of mouse metallothionein-I gene confers cadmium resistance in transgenic tobacco plants. Plant Molecular Biology 242: 341-351.

Pandey, V. C., Pandey, D. N. \& Singh, N., 2015. Sustainable phytoremediation based on naturally colonising and economically valuable plants. Journal of Cleaner Production 86: 37-39.

Pandharipande, S. L. \& Gadpayle, P. 2016. Phytoremediation studies for removal of copper and chromium using Azolla pinnata and water hyacinth. International Journal of Innovative Research in Science, Engineering and Technology 5: 7078-7083.

Park, J., Song, W. Y., Ko, D., Eom, Y., Hansen, T. H., Schiller, M., Lee, T. G., Martinoia, E. \& Lee, Y. 2012. The phytochelatin transporters AtABCC1 and AtABCC2 mediate tolerance to cadmium and mercury. The Plant Journal 692: 278-288.

Parzych, A., Sobisz, Z. \& Cymer, M., 2016.Preliminary research of heavy metals content in aquatic plants taken from surface water Northern Poland. Desalination and W ater Treatment 573: 1451-1461.

Paz-Ferreiro, J., Lu, H., Fu, S., Méndez, A. \& Gascó, G. 2014. Use of phytoremediation and biochar to remediate heavy metal polluted soils: A review. Solid Earth 51: 65-75.

Peng, J. S., Ding, G., Meng, S., Yi, H. Y. \& Gong, J. M. 2017. Enhanced metal tolerance correlates with heterotypic variation in SpMTL, a metallothionein-like protein from the hyper accumulator Sedum plumbirincicola. Plant, Cell and Environment 408: 1368-1378.

Pratas, J., Paulo, C., Favas, P. J. \& Venkatachalam, P., 2014. Potential of aquatic plants for phytofiltration of uraniumcontaminated waters in laboratory conditions. Ecological Engineering 69: 170-176.

Rahman, M. A. \& Hasegawa, H. 2011. Aquatic arsenic: phytoremediation using floating macrophytes. Chemosphere 835: 633-646.

Rai, P. K. \& Tripathi, B. D. 2009. Comparative assessment of Azollapinnata and Vallisneriaspiralis in $\mathrm{Hg}$ removal from GB Pant Sagar of Singrauli Industrial region, India. Environmental Monitoring and Assessment 148: 75-84.

Robinson, B., Kim, N., Marchetti, M., Moni, C., Schroeter, L. van den Dijssel., Milne, G. \& Clothier, B. 2006. Arsenic hyper accumulation by aquatic macrophytes in the Taupo Volcanic Zone, New Zealand. Environmental and Experimental Botany 58(1-3): 206-215.

Rodríguez-Bocanegra, J., Roca, N., Febrero, A. \& Bort, J. 2018. Assessment of heavy metal tolerance in two plant species growing in experimental disturbed polluted urban soil. Journal of Soils and Sediments 18: 2305-2317.

Sarwar, N., Imran, M., Shaheen, M. R., Ishaque, W., Kamran, M. A., Matloob, A., Rehim, A. and Hussain, S., 2017.
Phytoremediation strategies for soils contaminated with heavy metals: modifications and future perspectives. Chemosphere 171: 710-721.

Sharma, A. \& Sachdeva, S. 2013. Azolla: role in phytoremediation of heavy metals. International Journal of Engineering Sciences 914.

Salam, M. M. A., Kaipiainen, E., Mohsin, M., Villa, A., Kuittinen, S., Pulkkinen, P., Pelkonen, P., Mehtätalo, L. \& Pappinen, A. 2016. Effects of contaminated soil on the growth performance of young Salix salixschwerinii EL Wolf and the potential for phytoremediation of heavy metals. Journal of Environmental Management 183: 467-477.

Salem, H. M., Eweida, E. A. \& Farag, A. 2000. Heavy metals in drinking water and their environmental impact on human health. ICEHM2000, Cairo University, Egypt. pp. 542-556.

Salzman, M. B., Smith, E. M. \& Koo, C. 2002. Excessive oral zinc supplementation. Journal of Pediatrichematology/Oncology 247: $582-584$.

Sarwar, N., Imran, M., Shaheen, M. R., Ishaque, W., Kamran, M. A., Matloob, A., Rehim, A. \& Hussain, S. 2017. Phytoremediation strategies for soils contaminated with heavy metals: Modifications and future perspectives. Chemosphere 171: 710-721.

Semple, K. T., Morriss, A. W. J. \& Paton, G. I. 2003. Bioavailability of hydrophobic organic contaminants in soils: fundamental concepts and techniques for analysis. European Journal of Soil Science 544: 809-818.

Shackira, A. M. \& Puthur, J. T. 2017. Enhanced phytostabilisation of cadmium by a halophyte-Acanthus ilicifolius L. International Journal of Phytoremediation 194: 319-326.

Sherene, T. 2010. Mobility and transport of heavy metals in polluted soil environment. Biological Forum - An International Journal 22: 112-121.

Slatter, K. A. 1998. Nickel accumulation and tolerance in Berkheyacodii and its application in phytoremediation. M.Sc. Project. pp. 178.

Sobariu, D. L., Fertu, D. I. T., Diaconu, M., Pavel, L. V., Hlihor, R. M., Drăgoi, E. N., Curteanu, S., Lenz, M., Corvini, P. F. X. \& Gavrilescu, M. 2017. Rhizobacteria and plant symbiosis in heavy metal uptake and its implications for soil bioremediation. New Biotechnology 39: 125-134.

Sukumaran, D. 2013. Phytoremediation of heavy metals from industrial effluent using constructed wetland technology. Applied Ecology and Environmental Sciences 15: 92-97.

Suman, J., Uhlik, O., Viktorova, J. \& Macek, T. 2018. Phytoextraction of heavy metals: a promising tool for cleanup of polluted environment. Frontiers in Plant Science 9: 1476.

Syukor, A. A., Sulaiman, S., Siddique, M. N. I., Zularisam, A.W. \& Said, M. I. M., 2016. Integration of phytogreen for heavy metal removal from wastewater. Journal of Cleaner Production 112: 3124-3131.

Tangahu, B. V., Abdullah, S., Rozaimah, S., Basri, H., Idris, M., Anuar, N. \& Mukhlisin, M. 2011. A review on heavy metals $\mathrm{As}, \mathrm{Pb}$, and $\mathrm{Hg}$ uptake by plants through phytoremediation. International Journal of Chemical Engineering.

Tiwari, M., Sharma, D., Dwivedi, S., Singh, M., Tripathi, R. D. \& Trivedi, P. K. 2014. Expression in Arabidopsis and cellular localisation reveal involvement of rice NRAMP, OsNRAMP 1, in arsenic transport and tolerance. Plant, Cell and Environment 37 (1): 140-152.

Tripathi, R. D., Srivastava, S., Mishra, S., Singh, N., Tuli, R., Gupta, D. K. \& Maathuis, F. J. 2007. Arsenic hazards: strategies for tolerance and remediation by plants. Trends in Biotechnology 25(4): 158-165.

Turgut, C., Pepe, M. K. \&Cutright, T. J. 2004.The effect of EDTA and citric acid on phytoremediation of $\mathrm{Cd}, \mathrm{Cr}$, and $\mathrm{Ni}$ from soil using Helianthus annuus. Environmental Pollution 1311: $147-154$. 
Ullah, A., Mushtaq, H., Ali, H., Munis, M. F. H., Javed, M. T. \& Chaudhary, H. J. 2015. Diazotrophs-assisted phytoremediation of heavy metals: a novel approach. Environmental Science and Pollution Research 224: 2505-2514.

Ullah, A., Heng, S., Munis, M.F.H., Fahad, S. and Yang, X., 2015. Phytoremediation of heavy metals assisted by plant growth promoting (PGP) bacteria: a review. Environmental and Experimental Botany 117: 28-40.

Panchal, V., Ghosh, A., Tomar, P. C \& Chapadgaonkar S. S. 2020. Decolourization of Yamuna water using peanut hull in packed bed reactor. Rasayan Journal of Chemistry 13: 949-954.

Wen, X. P., Pang, X. M., Matsuda, N., Kita, M., Inoue, H., Hao, Y. J., Honda, C. \& Moriguchi, T. 2008. Over-expression of the apple spermidine synthase gene in pear confers multiple abiotic stress tolerance by altering polyamine titers. Transgenic Research 172: 251-263.

Wuana, Raymond A., \& Felix, E. Okieimen. 2011. Heavy metals in contaminated soils: a review of sources, chemistry, risks and best available strategies for remediation. Ecology 2011: 1-20.

Xia, Y., Qi, Y., Yuan, Y., Wang, G., Cui, J., Chen, Y., Zhang, H. \& Shen, Z. 2012. Overexpression of Elsholtriahaichowensismetallothionein 1 EhMT1 in tobacco plants enhances copper tolerance and accumulation in root cytoplasm and decreases hydrogen peroxide production. Journal of Hazardous Materials 233: 65-71.

Yanqun, Z., Yuan, L., Jianjun, C., Haiyan, C., Li, Q. \& Schvartz, C., 2005.Hyperaccumulation of $\mathrm{Pb}, \mathrm{Zn}$ and $\mathrm{Cd}$ in herbaceous grown on lead-zinc mining area in Yunnan, China. Environment International 315: 755-762.

Yobouet, Y. A., Adouby, K., Trokourey, A. \& Yao, B., 2010. Cadmium, copper, lead and zinc speciation in contaminated soils. International Journal of Engineering Science and Technology 25: 802-812.

Zhang, X., Xia, H., Li, Z. A., Zhuang, P. \&Gao, B. 2011. Identification of a new potential Cd-hyperaccumulator Solanumphoteinocarpum by soil seed bank-metal concentration gradient method. Journal of Hazardous Materials 189(1-2): 414-419.

Zhang, Z., Wen, X., Huang, Y., Inoue, C. \& Liang, Y. 2017. Higher accumulation capacity of cadmium than zinc by Arabidopsis halleri ssp. germmifera in the field using different sowing strategies. Plant and Soil 418: 165-176.

Zhuang, P., Ye, Z. H., Lan, C. Y., Xie, Z. W. \& Shu, W. S 2005. Chemically assisted phytoextraction of heavy metal contaminated soils using three plant species. Plant and Soil 276: 153-162. 